\title{
Critical discourse analysis on the news about terrorism: An analytical study on Turkish media
}

\author{
Aykut Töngür ${ }^{1}$ \\ Hakan Batırhan Kara ${ }^{2}$
}

\begin{abstract}
Today, combating terrorism is accepted as an international issue. Turkey has struggled with this problem for years. Combating terrorism is not only a matter for the state or government to address, but nongovernmental organizations must be contribute to the process of developing strategies and policies against terrorism. Media organs may have contribution in fighting against terrorism and newspapers which can be tools to combat terrorism are the subject of this study. Three newspapers were selected as samples of this study and news reports relating to terror and terrorism in these newspapers were analyzed according to Van Dijk's Critical Discourse Analysis. As a result of the findings of this study, it is seen that media organs are not free from biases and ruling ideology and political view effects newspapers, magazines or televisions while presenting terror news. At the end of the study, some suggestions were developed especially for the stakeholders in the fight against terrorism.
\end{abstract}

Keywords: Terror; Terrorism; Terror News; Critical Discourse Analysis; Media.

\section{Introduction}

Terrorism is an issue as old as human history and remains a current problem on a global scale. Until recently, terrorism was perceived as an issue related with security and state. However, it is seen today that it is a problem which can be solved by way of developing social policies, as well as through the participation of NGOs and the cooperation of the international community.

The press approach and presentation of terror news in the media are very important. The press has the potential to misguide the society, affect the fight against terrorism in negative ways, unintentionally support terrorism by supporting the racism, and develop wrong perceptions among the general public as a result of how it handles the terrorism issue. Therefore, studying the dynamics of terror news as spun by the media is crucial and hence why this is the subject of the current study.

In this study, samples were selected from the national newspapers in Turkey. Terror news as reported in these newspapers is the scope of this study. Before the analysis part of the study, some explanations were provided about the terms relating to terror and terrorism. Besides, various studies that analyzed these terms in the press in Turkey were discussed in this study. Then, some information was provided about the critical discourse analysis, which is the method employed for this study. Finally, news about terror in the selected sample newspapers was

\footnotetext{
${ }^{1}$ Ph.D, Corresponding Author, Tukish Interior Ministry, atongur@yahoo.com

2 Ph.D, Turkish Interior Ministry, hakanbatirhan@yahoo.com
} 
Töngür, A., \& Kara, H. B. (2016). Critical discourse analysis on the news about terrorism: An analytical study on Turkish media. International Journal of Human Sciences, 13(1), 1629-1643. doi:10.14687/ijhs.v13i1.3663

analyzed via the critical discourse analysis method and as a result, some suggestions were developed for practitioners and theoreticians conducting studies on this topic. This study aims to answer the questions, "Are media organizations free from biases while presenting terror news?" and "Does ideology or political viewpoint affect the newspaper, magazine or television industries while these are presenting terror news?" While seeking answers for these questions, the Critical Discourse Analysis was used to analyze how terror news is reported in the media.

\section{Media and Terrorism}

Terror is an issue as old as human history. Etymologically, the term 'terror' derives from the Latin word "terrere". Today, the term terror is being discussed in the international arena; however, this term was defined in different ways in different states and there is no common, homogeneous definition of it. In one definition, terrorism is described as physical violence committed intentionally by an individual, organization, or a state, targeting innocent people or animals in order to reach religious, political, economic, or ideological targets (Best and Nocella, 2006).

In recent years, terrorism has gained recognition as one of the biggest problems faced by Turkey on the local level. In fact, terrorist organizations active in Turkey are the result of unsolved problems from the time of the Ottoman Empire. According to Altun (2013), the new Turkish Republic was denied the multi-identity structure and attempted to build a single identity structure. This resulted in ethnicity-based separatist terror. According to Koseli (2006), there is no one reason for terrorism. On the contrary, there are many reasons for terrorism, such as social, economic, and political motivations. At this point, Altun suggests that the political discourse based on single identity be given up and that multi-identity policies be developed in order to solve the terror problem. On the other hand, Koseli suggests that improvements have to be made to overcome certain problems, particularly poverty, unemployment, educational system malfunctioning, and inequality and lack of opportunity.

Once, the combating terrorism issue was accepted as referring only to an armed struggle. Thousands of terrorists, civilians, and law enforcement officers who have been killed in these years showed that the terrorism problem cannot actually be solved by only developing security policies - which must be done by the government. After understanding this fact, NGOs have started to participate in efforts relating to this struggle and social projects are developed to counter terrorism (Altun, 2014; Akbulut and Beren, 2012). In this new perspective, the government and NGOs are expected to be inclusive and not exclusionary, as well as to provide social peace and reconciliation in this struggle.

The press is one of the tools used in combating terrorism because news about terrorism has psychological effects on society (Demirli, 2011). The press has the potential to serve or combat terrorism as a result of this effect (Amichai, 2009). The press can report terror news in such a way as to divert attention from its core and can thus cause a negative effect that counters the struggle against terrorism (Yurdigül and Balc1, 2012:296). Therefore, the manner in which the press handles and presents terror news to the public is of the essence. From this point onward, this study will explore the literature pertaining to the topic as it applies to Turkey.

There is a limited number of studies in Turkey that discuss the press' spin on the terrorism issue. In one of these studies (Durna and Kubilay, 2010b), news items detailing incidents of kids throwing stones at the police were analyzed. According to this study, there was an attempt to hide violence committed by the police (Durna and Kubilay, 2010b). This study mentions that Kurds were referred to as 'them' by the mainstream media, particularly those channels closest to the government. This type of media excluded the Kurds from society, treating them as outcasts, and developed negative perceptions about Kurds. The study also shows that the newspaper 'Taraf' did not adopt this kind of approach as employed by other media outlets. Therefore, it can be claimed in this case that Van Dijk's term ' $u$ ' would point at the State (or Government) and the term 'them' would point to the Kurds. 
Töngür, A., \& Kara, H. B. (2016). Critical discourse analysis on the news about terrorism: An analytical study on Turkish media. International Journal of Human Sciences, 13(1), 1629-1643. doi:10.14687/ijhs.v13i1.3663

In another study, Karduman and Batu (2011) claim that, while generating the news texts, the news source, media agency, editor, and politics are very influential. As a result of this influence, the news passes through a process and at the end, the text reflects the ruling ideology. In this study, it is stated that, while developing texts for terror news, sentences were developed according to the passive structure and the media called for the public common sense. On the other hand, in news about "law and order", sentences were developed according to active structure and the law enforcement became the subject of these sentences. Again in this study, it is also stated that, in terrorist activities, terrorists were described as "active agents" and law enforcement was described with passive verbs. In specific news reports, murdered law enforcement officers (polices, soldiers, rangers, etc.) were sanctified as martyrs and linked to the ruling ideology. In the news, it was stated that the behaviors of the martyrs' families were appreciated. Besides, the authorities' and ruling people's explanations were described with the use of strong words such as stated, mentioned, explained, but, on the other hand, the explanations of others were reported using simple words, such as claimed, asserted. It is also stated in the study that news items originated from certain accredited sources and other, alternative sources were not be given the chance to provide the news.

While generating the news about terrorist activities, the main trend is to talk about counteracting the terrorists who oppose the ruling powers, discuss a reduction of the power of terrorist organizations, debate how to overcome terrorist activities, and focus on the prevention of any activities that threaten the permanence of the status quo by law enforcement (Karaduman and Batu, 2011:369).

\section{Kurdish Question in Turkey}

Kurds mainly live in Turkey, Iraq, Iran, and Syria. Russia also has a small Kurdish population. Kurds have a long history in the region that dates back by 4000 years. They have escaped the cruel and oppressive rule of Zahhak by retreating to the mountains and after that, they forgot about civilization, art, and culture, and developed their own language. The region was conquered by Arabs in the 7th century and then, the majority of Kurds became Muslim. Today, almost all Kurdish people are Muslim and Sunni (Balci, 2008; McDowall, 2003).

The Kurdish issue was put on the agenda in Turkey especially after World War I. As a matter of fact, there were some problems between Turks and Kurds, especially in last decades of the Ottoman State rule; but, at that time, most of the Kurds had a commitment to the State so the separatist movements were not supported by a majority of the Kurds. Moreover after World War I, the Kurds and Turks fought together and supported each other during the Turkish War of Independence. In 1923, the Turkish Republic was established as a result of the collapse of the Ottoman State and this new established State adopted westernization, and nationalist and secular policies. However, the Kurds were displeased and angered by these policies and did not support them. The new Turkish government gave special minority status to people who were not Muslim, such as Armenians, Greeks, and Jews. These were recognized populations by western powers and this policy was adopted as a result of the pressure of these powers. The new government lead by Mustafa Kemal interpreted Turkish Nationalism to reflect a monocultural state and, unlike nonMuslim populations, the new leadership rejected the ethnic and cultural differences among Muslim populations. This sparked the Kurdish issue in Turkey, which continued to have political, social, and economic effects on the State in the early 21st century (Birand, 1992; Bozarslan, 2003; Ciment, 1996; Balci, 2008).

Besides, two important developments affected the Kurdish issue in Turkey seriously in time. The first was nationalist movements in the world and the second was the human rights issue that is widely discussed globally today. These developments provided a suitable environment for Kurdish Nationalists to support their arguments (Kutschera, 1994, Yavuz, 2001, Bozarslan, 2003). 
Töngür, A., \& Kara, H. B. (2016). Critical discourse analysis on the news about terrorism: An analytical study on Turkish media. International Journal of Human Sciences, 13(1), 1629-1643. doi:10.14687/ijhs.v13i1.3663

In time, Kurdish Nationalist movements were radicalized. As a result of the migration of Kurds from villages in the eastern part of Turkey to the huge cities in the western part of Turkey, they faced many economic and social problems. Besides, they have seen the great disparities between western cities and their own eastern cities. This awareness and the ensuing problems as a result of the Kurds' urbanization and massive migration in turn resulted in Kurdish radicalization (Birand, 1992; Bozarslan, 2003; Kutschera, 1994).

The most radical Kurdish organization is the Kurdistan Workers Party, which, in the Kurdish language, is called, Partiya Karkerên Kurdistanê (PKK). In the 1960s and 70s, Kurdish leftist Marxist movements and nationalist movements were very effective in contributing to the constitution of the PKK. The PKK formed the Kurdish Nationalist and Political Movement by effectively using violence and it can be claimed that the organization became successful in this way to reach its goal. The PKK was established by Abdullah Ocalan and others in his circle in 1974 in Ankara. Their group was called the Ankara Democratic Patriotic Association of Higher Education. Their goal was to promote and support the Kurdish language and culture. They also wanted their race, language, and culture to be recognized, both politically and socially. Abdullah Ocalan was a member of Revolutionary Youth (Devrimci Gençlik), which was a leftist youth movement. Therefore, the PKK originated from a Marxist-Leninist ideology and it aimed to provide independence for Kurds, as well as set up the great Kurdistan in the Middle East (Barkey, 2000; Birand, 1992; Imset, 1992)

At first, especially between 1978 and 1980, the PKK was involved many activities in order to provide awareness, introduce its ideology, and for nationalist propaganda. It tried to form a party substructure and gain mass support especially in the region. On the other hand, since the organization needed funds to sustain itself, it engaged in some illegal activities, such as robberies and drug trafficking (Gunter, 1997).

The military intervention of the Turkish Government in September 1980 interrupted PKK activities. However, the new government, which consists of military members, did not see the PKK as a threat and did not fight against them. After the intervention, Abdullah Ocalan and his friends lived in Syria and Iraq for a while. Beginning from 1984, the PKK started armed, violent terrorist activities in southeast Turkey. The PKK targeted not only military bases and police units, but also civilians (Birand, 1992; Imset, 1992; Gunter, 1997). Since then, the PKK has remained an issue as its actions have had negative political, social, and economic effects in Turkey. This study analyses the discourse of Turkish media while reporting terror news and answers the question "Does the ideology or political view effect newspapers, magazines, or televised media in the reporting of news items on terror?".

\section{Methodology: Critical Discourse Analysis}

Today, many methods of communication have been developed and in this environment, many researchers gained interest in analyzing the dynamics of how the press gathers and reports the news. In the literature, components of the news, such as photographs, texts, and images, have been the subjects of studies. One of the methods used in these studies is the Critical Discourse Analysis. In this study, the method developed by Teun Van Dijk was used.

Before defining the Critical Discourse Analysis, the relationship among some terms should be understood. First of all, the relationship between discourse and ideology should be explained. The issue of discourse was actually not brought to the literature first by Teun Van Dijk. It is claimed that the root of the term is as old as 2000 years (Şeker, Rengim and Çavuş, 2012). Van Dijk only analyzed meanings inherent or attributed to this term. While analyzing the news reported by the press, Van Dijk put forth that an ideology generates news to rule the society and develop perceptions in the desired way. Here, he points out that there is a relationship between discourse and ideology.

Therefore, ideology has effect on both the process of news generation and the perception of it by society (Tuchman, 1978; Şeker, Rengim and Çavuş, 2012:381) because, in all these 
Töngür, A., \& Kara, H. B. (2016). Critical discourse analysis on the news about terrorism: An analytical study on Turkish media. International Journal of Human Sciences, 13(1), 1629-1643. doi:10.14687/ijhs.v13i1.3663

processes, individuals in society are being affected by the ruling ideology. Moreover, according to Shoemaker and Reese (1996), society-ruling elites use the media to maintain their power and position. Therefore, there is a strong relationship between the ruling ideology and the discourse of the media. Elites carry their messages, which they would like to impose on society, in hidden or clear format by way of the media (Gitlin, 1980; Şeker, Rengim and Çavuş, 2012). That is to say, while the discourse of the media is in effect the message to the society, ideology is the element which determines the format of this discourse (Sigal, 1974; Gans, 1979; Karaduman and Batu, 2011:362).

The 'discourse' is a key term of an institutional approach which suggests to interpret power relations in society by way of language's potential of signification and presumes that, as a result of this, potential realities always change in society (Durna and Kubilay, 2010a:48). Shortly, the discourse can be defined as the language of the ruling ideology in the media, through which use it strives to keep the power. This language is not always employed clearly in the texts, but is sometimes used in the hidden form. That is to say, wordplay may be found in the texts in some cases (Göka, Topçuoğlu and Aktay, 1999). This wordplay is intentionally inserted to reflect the newspaper's ideology. For example, a news report about a murder case may present the victim is presented as "martyrized" in one newspaper while, in another, as simply, "killed". The selection of the terminology with which to report the news reveals the stance or ideology supported by the newspaper.

Durna and Kubilay (2010a) accept Saussure as the one who initiated the development process of the term 'discourse'. Moreover, they talk about Foucault as a pioneer on this issue. According to these scholars, Foucault claims that the ruling power extends its influence to all parts of daily life. The ruling power insists on conducting its discourse to society in a positive and hidden way (sometimes coloring their statements with scientific facts). Many studies have analyzed this relationship between the ruling power and society. In this area, one of the discourse analysis methods is the Critical Discourse Analysis.

The Critial Discourse Analysis method was developed by Teun Van Dijk and it can be defined as systematic analysis of clear or hidden causation and the determination of relationships among discursive practices, events, texts, social and cultural structures, relations, and processes (Durna and Kubilay; 2010a). Teun Van Dijk attracted attention by adopting his Critical Discourse Analysis method in his studies on media and the news. Van Dijk accepts a news report as a form of discourse and according to him, discourse is not formed as a result of the process of information collection (1988:19). This is because the reporter cannot often witness the case in real time. In this case, the reporter generates the news by collecting information from eye witnesses, governmental authorities, and some documents. This means that the reporter reproduces the news by passing the discourses of different sources about the news through a process.

According to Van Dijk, the media is the voice of the ruling ideology. In this ideology there is a distinction of "us" and "them". In this distinction, "us" is generally being reflected in a positive way and "them" in a negative way (Van Dijk, 1982; 2006). In this dual distinction, texts for the news are being determined and generated by the ruling ideology and in this way, the ruling ideology rules and forms the society (Bilgin, 2014). While doing this, the ruling ideology generates texts in accordance with the accepted norms of the society (Van Dijk, 1988; Bilgin, 2014). There are three stages in Van Dijk's analysis method, which are text, generation of the news, and interpretation. Van Dijk analyses the relationship among these three stages in two ways: micro analysis and macro analysis (Van Dijk, 1988). Micro Analysis covers 1. Determination of the terminology, 2. Structure of sentences, 3. Causality, 4. Rhetoric. Macro Analysis covers 1.Thematic, 1.1. Headlines, 1.2. Top title, 1.3. Subtitle, 1.4. News Entries, 1.5. Spot, 2. Schematic, 2.1. Case, 2.2. Interpretation.

In the macro structure of thematic analysis, the title, top title, subtitle, spot, and introduction of the news is analyzed. Here, the relation between the title of the news and the text 
Töngür, A., \& Kara, H. B. (2016). Critical discourse analysis on the news about terrorism: An analytical study on Turkish media. International Journal of Human Sciences, 13(1), 1629-1643. doi:10.14687/ijhs.v13i1.3663

of the news is investigated. In this analysis, the title of the news is investigated whether it is reflecting the news text meaning or not. In the case part of the schematic analysis, it is investigated whether the news text is reflecting the case exactly or not. Besides, the flow of the case and results are also investigated here. In the interpretation part, the sources of information and statements from all parties are investigated (Van Dijk, 1988). In this case, the schematic structure determines the thematic structure. Therefore, there must be a relationship between these two structures. Shortly, the titles, spot, and introduction of the news are determined by the TV or text news report.

The main purpose of this study is answering the question, "How do newspapers perceive and report counterterror operations and terrorist activities?"; "Are media organizations free from biases while presenting terror news?" and "Does the ideology or political view influence newspaper, magazine or television reporting while presenting terror news to the public?". This study also develops suggestions for the practitioners and theoretician in the perspective of these answers. The newspapers Hurriyet, Taraf, and Yeni Safak are samples for this study. The newspaper Hurriyet was selected as a sample since it considered as mainstream media in public and has a wide readership in Turkey. The newspaper Yeni Safak was selected as a sample since it considered in public as the supporter of the government and the newspaper Taraf was selected for its apparent critical approach to the government's counterterrorism policies.

In this study, news about terrorist activities and counterterror operations reported in these newspapers as issued between the dates May 15th, 2011 and May 15th, 2014 were analyzed. Another purpose of this analysis is also to discover the difference in the news reports relating to terrorism before and after the development of counterterrorism policies and the Kurdish issue policy of the current government, which is referred to as the peace process (ç̈züm sïreci). Herein, an attempt is also made to see how the ruling ideology affects the terror news. Within this scope, only terror news items published in the first pages of newspapers in the abovementioned time period in only the first pages were analyzed. Mainly, terrorism news about counterterror operations, terrorist attacks, ambushes, and bombing attacks were analyzed and discussed. News about demonstrations carried out by terrorist organizations' members or supporters is not covered by this study. This study analyzed published news articles in the three abovementioned newspapers within the stated time period by the way of Van Dijk's critical discourse analysis method according to those news' Macro Structural Features.

\section{Macro Structural Features \\ Thematic analysis \\ Headlines}

The first thing that attracts attention in the article headlines of newspaper Hurriyet is that specific different adjectives and verbs are used for law enforcement officers and terrorists killed in terrorist activities and counter terror operations. Hurriyet presents police and soldiers killed in counter terror operations or terrorist activities as martyrs. For example: Two police officers become martyrs in Osmaniye; First mine trap then attack in Şemdinli: 4 soldiers become martyrs.

On the other hand, this newspaper describes members of a terrorist organization that are killed in operations as 'killed' or 'dead'. For example: Operation at the border: 12 members of PKK are killed; Terrorist killed. Hurriyet uses the terms 'killed' or 'dead' also in the case of civilians.

PKK attacked to women while they were going to a wedding: 4 women killed

Hurriyet uses religious honorific statements for slain law enforcement officers and neutral statements for dead terrorists and civilians. By way of this latter negative presentation, the separation of $u$ and them is also stressed in a hidden way. Accordingly, law enforcement officers are presented as us since they are defending the state but, on the other hand, terrorists and other civilians are presented as them as a result of this hidden separation.

Another issue, which is attracting attention in the newspaper's news headlines, is that provinces and locations in which terrorist activities happened in eastern Turkey are revealed. The 
Töngür, A., \& Kara, H. B. (2016). Critical discourse analysis on the news about terrorism: An analytical study on Turkish media. International Journal of Human Sciences, 13(1), 1629-1643. doi:10.14687/ijhs.v13i1.3663

newspaper reports the news about the terrorist activity by stating the name of the province or location of that activity. For example: 4 martyrs in Cukurca; 5 martyrs in Semdinli.

Whereas, while the newspaper Hurriyet reports terrorist activities committed in western Turkey, the location or name of the province is never stated, even when the terrorist activity is very serious and sensational. For example, the terrorist bombing attack committed in Ankara Kumrular, a few hundred meter away from the prime minister's office was reported merely as the Tube Bomb in November $21^{\text {st }}, 2011$, without any mention of location. Shortly, while the newspaper Hurriyet was reporting the news in western Turkey, the location of this particular incident was not mentioned in the text and readers' attention was diverted to other aspects of the case. Besides, the newspaper associates terrorist activities with the eastern and southeastern part of the country, which is mostly inhabited by the Kurdish population.

Another issue with Hurriyet was that while the newspaper was reporting the terrorist activity in which the law enforcement officer was killed, it used language to call to the individual and collective conscience, appealing to the religious, moral, and social mores of the society. The newspaper is thus known for presenting the news in an emotional context. For example, news titles such as, Oh mummy, they shot me: 5 Martyrs on the mountain of Cudi; Unborn baby remained fatherless; Farewell to the martyred Police Officer, appeal to the public conscience.

Another issue is that the newspaper uses a terminology that expresses hatred toward certain individuals or organizations. Hurriyet presented the news about the terrorist attack as Strong response from President Gul: Our revenge will be great. Besides, the newspaper often uses words such as 'delinquent', 'treacherous', 'traitors' and 'revenge'. For example: Delinquent attack: 7 martyrs; Traitor attack are such terms used by Hurriyet that incite hatred.

Besides, Hurriyet also uses sentences in active voice while reporting cases in which members of terrorist organizations are perpetrators and law enforcement officers are victims. In this choice of language, the newspaper also hides the identity of the perpetrator in order to present a strong image of state and law enforcement. Titles such as 2 police officers are martyrs in Osmaniye are an example of their technique.

Then, on the other hand, the newspaper uses passive voice, such as, Terrorist was killed, to describe cases in which law enforcement officers are perpetrators and terrorists are killed. For example: The operation at the border: 12 terrorists killed; 27 terrorists killed at the mountain of Cudi.

Therefore, the newspaper uses different structures for sentences when writing news texts about perpetrators of a crime. In this way, Hurriyet presents law enforcement officers as strong and thus accepted as us by the newspaper. On the other hand, terrorists who are accepted as 'them' are presented as weak by the newspaper.

Finally, in the news titles, the newspaper stresses the genders of slain terrorists. If there are women killed as a result of the counterterror operation, the newspaper emphasizes this in the headline of the news report. For example: 15 members of PKK killed in Bitlis: Most are women.

The other sample newspaper of this study, Yeni Safak, presents news also in the same way. Yeni Safak also creates an image of law enforcement officers losing their lives in counterterror operations as martyrs. The military team was ambushed while seeking help: 5 martyrs is an example of a news title from Yeni Safak. As in the newspaper Hurriyet, Yeni Safak also describes dead terrorists as simply 'killed' in the headlines. For example; A member of PKK who is responsible for Mardin was killed. Besides, the newspaper also uses the term of defused apart from the term of killed for the terrorists. For example; 14 terrorists were defused; attacking terrorists could not escape in Sirnak: 8 terrorists were defused.

On the other hand, the newspaper Yeni Safak does not use specific words for civilians killed in terrorist attacks. The newspaper uses different terms, such as 'murdered', 'dead', 'martyrs' to describe the fate of these civilians. Therefore, this newspaper's approach in this context is thus not clear.

Yeni Safak describes law enforcement officers and sometimes civilians as victims and aggrieved by using terms such as 'martyr' and 'murdered'. The newspaper tries to present law 
Töngür, A., \& Kara, H. B. (2016). Critical discourse analysis on the news about terrorism: An analytical study on Turkish media. International Journal of Human Sciences, 13(1), 1629-1643. doi:10.14687/ijhs.v13i1.3663

enforcement officers and civilians as $u s$ within the society in this way, while treating terrorists as them by using terms that will exclude them from society.

Like Hurriyet, Yeni Safak also avoids mention of the location of terrorist activities if the event occurs in western Turkey; but, if it happens in eastern Turkey, the location is stressed in the headlines, in which case the province names are disclosed, such as Hakkari, Sirnak, and Cukurca. Pain in Hakkari and Sirnak; Six soldiers, two guards are martyrs in Cukurca. The newspaper headline for the bombing attack in Foca Izmir on August 10th, 2012 was: Semdinli bomb to Soldiers. Therefore, while avoiding disclosure of the location of a terrorist activity in western Turkey, the newspaper also identifies the terrorist activity within the Semdinli province, which is located in eastern Turkey. This shows that the newspaper accepts the western part of Turkey as us and the eastern part of Turkey as them.

Another issue brought forth in this newspaper's headlines is the use of hatred terminology. This approach is similar to that employed by Hurriyet. Terms such as traitor and treacherous are liberally used. 3 soldiers are martyrs in the treacherous ambush in Amanos; You're the killer are some examples.

The newspaper also identifies terrorists and terrorist activity with terms such as 'killer', 'betrayer', and 'fascist'. On the other hand, the newspaper describes counterterrorism operations with honorific and sanctifying terms. For example: Blow to the dirty plan on the mountain of Goman...; They have learned the lesson in Semdinli: 26 terrorists were killed. By using this kind of terminology, including terms such as huge operations, stroke, impact, giving lesson, cleanse, the newspaper exalts the $u s$.

Another issue is the use of active or passive sentence structure in the headlines. The newspaper Yeni Safak often uses the passive sentence structure with the term 'were killed' for terrorists. 8 terrorists were killed: 5 of them were women; 15 terrorists were killed; The terrorist responsible for Silvan was killed are some examples.

On the other hand, the active or passive sentence structures are not employed in reference to the law enforcement officers. For example, the newspaper headlines may say something like: 5 martyrs on the Mountain of Cudi; 2 martyrs in Tunceli; 3 martyrs on the Mountain of Zel to head an article about counterterrorism operations. As it is seen in headlines, the newspaper also makes use of the word 'martyr' as an adjective to describe slain law enforcement officers.

For civilians who become targets of terrorist activities, the newspaper uses sentences in active structure, for example, Treacherous terrorists murdered civilians and Fascist killed a baby again.

Yeni Safak takes almost the same approach as Hurriyet. In this approach, it can be claimed that the newspaper Yeni Safak tries to deliver a message about a 'strong' state and law enforcement (us) and a 'weak' terrorist organization (them).

The third and final newspaper analyzed in this study is Taraf. The first thing that attracts attention in this newspaper's headlines is that it uses the same terms, no matter whether the victim is a terrorist, civilian, or law enforcement officer. The newspaper uses the term 'dead' for all these cases. In this perspective, the newspaper tries to show its respect for human rights and right to live. Therefore, Taraf employs a different approach than Hurriyet and Yeni Safak, which tend to lean toward the ruling ideology with their news headlines.

The second issue in the headlines of the Taraf is that the newspaper conveys an image of terrorist activities and counterterror operations in such a way as to paint it as a war between law enforcement and the terrorist organization. The newspaper presents both sides as warlike with its headlines. For example, They love war; And the peace dies; Guns speak: 14 dead. Both sides are depicted as having a desire or thirst to 'kill'. The headline, They could not reach agreement for the casualties shows this particular perspective.

In the case of murdered civilians as a result of terrorist activities, the newspaper reacts with headlines such as: Women's killers; Bloody wedding; They killed his mother.

Terms expressing hatred in Tarafs headlines is another outstanding issue. For example: Treacherous execution for 2 soldiers; Bloody ambush in Beytussebab. Besides, the articles in Taraf 
Töngür, A., \& Kara, H. B. (2016). Critical discourse analysis on the news about terrorism: An analytical study on Turkish media. International Journal of Human Sciences, 13(1), 1629-1643. doi:10.14687/ijhs.v13i1.3663

sometimes touch on society's values with headlines such as: They killed his mother; one more mother's baby is dead to appeal to the public's emotions.

The final issue to stress here is the use of sentences in both active and passive voice. The newspaper uses active voice in cases where a law enforcement representative is the perpetrator, such as Soldiers hit plumbers; The Government bombed the public: 35 dead. On the other hand, headlines referring to the same perpetrators in the passive voice would read like: 12 members of the PKK were killed in Uludere; PKK's winter camp was surrounded: 20 terrorists were killed. The newspaper also uses active voice when the PKK is the perpetrator: the PKK bit the police; the PKK attacked the police station in ambush: 5 police dead. However, for cases in which both law enforcement officers and terrorists are perpetrators, the headlines will be missing a verb: Bloody wedding; Mine trap for the police in Cukurca are some examples. In this way, the newspaper presents its approach, which is equality, respect for the human rights, and right to life. Therefore, this distinguishes Taraf from the other two newspapers.

\section{News Entries}

News entries in the newspaper Hurriyet carry the same structure as the news headlines. While the newspaper uses the term of died or was killed for terrorists, it refers to slain law enforcement officers as martyr. Therefore, it can be said that the specific language, including the discriminating terms used in the headlines, is also used in the news articles.

The second outstanding issue in the news entries of the newspaper Hurriyet is that there is no discrimination when it comes to stating the location of the operation or activity. Unlike the headlines, in news entries the newspaper stated locations or provinces for terrorist activities in all parts of Turkey.

The third outstanding issue is that the newspaper presents news about terrorist activities in a subjective, negative way within the articles themselves. Here, information about terrorist activities is meant to address the social conscience and also contradict the social culture: The PKK attacked police while they return from farewell dinner; The PKK attacked police during soccer game; The police officer murdered by PKK had been married for just 3 months are some sample sentences from Hurriyet s articles. In these statements, the newspaper is trying to give the message that the terrorist activity goes counter to societal values. In these statements, law enforcement officers are presented as passive and vulnerable so that the illegality of the terrorist activity is stressed.

News entries in Yeni Safak are consistent with the headlines. First, while the newspaper uses the verb 'was killed' for terrorists, it uses the term 'martyr' for law enforcement officers. The newspaper keeps its discriminatory perspective of us and them also in news entries, as well as the passive voice: 'was/were killed'. On the other hand, the newspaper uses active structure while reporting about a law enforcement officer's death. This is consistent with the headlines' terminology.

In Yeni Safak, the name of the location of a terrorist activity is clearly given. In the news headlines, the newspaper gives details about the location if the terrorist activity has occurred in eastern Turkey. However, the same is not given if the activity has occurred in western Turkey. This perspective does not apply to the news articles/entries, which offer information about the location, regardless of which part of Turkey is involved.

Another issue is the terminology used to describe terrorists in the news articles. The newspaper sometimes uses hatred terminology: Terrorist murdered civilians; bloody provocation from terrorists; terrorists made humans shield are some examples. On the other hand, the newspaper uses religious terminology while discussing law enforcement officers' activities and operations, in order to exalt them. For example, the term 'martyr' is used also in news entries as in headlines, and terms such as 'impact', 'suppressed', 'blocked', and 'defused' are used to describe law enforcement operations. The newspaper describes victim law enforcement officers via terms such as: 'heart-burning news', 'hurtful news', or 'bad news. With this kind of approach, the newspaper is trying to provide a link and correlate law enforcement and society. 
Töngür, A., \& Kara, H. B. (2016). Critical discourse analysis on the news about terrorism: An analytical study on Turkish media. International Journal of Human Sciences, 13(1), 1629-1643. doi:10.14687/ijhs.v13i1.3663

In the next sample newspaper, Taraf's news entries are consistent with its headlines in terms of the presentation of the case. Similar terms are used, such as 'dead' or 'died' for all civilians, law enforcement officers, and terrorists. From this perspective, Taraf attempts to show its respect for human rights and the right to life. Yet, sometimes, the newspaper uses the term 'martyr' for law enforcement officers in headlines. In the news articles, Taraf condemns both terrorists and law enforcement because of constant fighting among them and their 'warlike' attitude. For example, one would find sentences like: ...war trap ended the dialogue...; ...violence and death again...; both tears and death ensue... These texts reflect the newspaper's perspective in its articles. With this wording and approach, Taraf claims that the problem can be solved not with battle but with peace and dialogue.

On the other hand, the newspaper attempts to address emotional issues resulting from terrorist activities. Taraf's view is that terrorism, violence, and battle are not the way to solve problems. The newspaper tries to defend its approach by using expressions that appeal to the public's emotions. One finds text that reads: Kurdish initiative and solution process began as hopeful step forward but mothers keep crying and people keep dying; The PKK attacked civilians-this reflects the newspaper's particular approach. These expressions show that the newspaper has a perspective that is different from that of the ruling ideology. The message is given that the fight between the state and the terrorist organization also harms civilians. Besides, the newspaper presents all parts of this fight as human and does not discriminate for the same terminology is used across the board. For example, the newspaper uses the term 'dead' for all the individuals who lose their lives as a result of terrorist activity, regardless of whether they are law enforcement personnel or members of a terrorist organization. Taraf attempts to show itself as a supporter of the peace. Through its news texts, the newspaper makes a claim that both sides should contribute toward ending the conflict and providing a peaceful environment.

\section{Schematic Analysis}

When news items in the newspaper Hurriyet are analyzed in terms of case and interpretation, it is seen that the news is presented exactly and clearly in the relevant texts. In the news text, it is seen that details about location, the events that occurred, the number of people injured or killed, and information on whether the event is ongoing or not are given. Meanwhile, the headline, lists the location and number of killed or dead people. After this, concise information is given within the news article about the location and how the event transpired, followed by disclosure of the number of casualties and martyrs. However, in some cases, the newspaper also provides in its commentary extra information about the victim law enforcement officers. For example, the location where an injured officer is treated, information about the family of a martyr, details about kids and the pregnancy of a martyr's wife, and an emotional statement made by the martyr before he died are given in the text. When the news is analyzed for the sake of interpretation, generally it is seen that news sources are not specified. However, if the source is specified, it would typically be official sources, or statements made by government representatives.

On the other hand, the newspaper does not offer personal opinions or reflections on the case at hand. While presenting the case in the news, the newspaper uses expressions to engage people's emotions and support social integrity. In doing so, the newspaper reflects the ruling power's stance. The motivations, background information, and social and economic effects of the terrorist activity and suggestions for solutions are offered in the news texts. During the time period of the current study, there was no policy change of the newspaper before and after the solution process.

When Yeni Safak is analyzed schematically, it is seen that the news is presented exactly in the case part of the text. Besides, very detailed information is provided in the texts and this information mainly reflects the power of the state over the society. The terrorist activity is described, including how many law enforcement officers and terrorists lose their lives, and certain 
Töngür, A., \& Kara, H. B. (2016). Critical discourse analysis on the news about terrorism: An analytical study on Turkish media. International Journal of Human Sciences, 13(1), 1629-1643. doi:10.14687/ijhs.v13i1.3663

other details are also included, such as whether an F16 fighter joined the operation, did task forces chase the terrorists, were the terrorists surrounded, and how was a large-scale operation launched. For example: Air-assisted operation was launched to arrest the fleeing terrorists; ... a large-scale operation was launched in the area; the operation was supported with Skorski helicopters; Terrorists were forced to withdraw to the Goman Mountains where an air blockade took place with F16 fighters and helicopters.

This particular writing style shows that the newspaper tries to allay a sense of dejection or demoralization within the society born from a perception that the government is weakened. All the details, such as location of the operation or terrorist activity, the form of the activity, number of casualties, and reports of the cessation of or ongoing circumstances of the event are provided in the news text.

Upon analysis of the newspaper policies, it transpires that the newspaper refers to the official sources and government representatives as the main source of the news. Besides, the message is given that the government is strong and successful in the fight against counterterrorism. The newspaper engages the emotions and reflects the cultural values of society with respect to the terrorism issue. The newspaper also shares details such as descriptions and/or mention of planes, helicopters, armored vehicles, and task forces which the government took advantage of during the operation. In spite of providing all these details, the newspaper does not share information about the background or motivations behind the incident, or its social and economic effects. Besides, as is the case with Hurriyet, no difference was detected in the newspaper's policies before and after the solution process.

The final newspaper analyzed schematically is the Taraf. In the case part of the news text in Taraf, it is seen that the newspaper shares details such as the location, date, and names of individuals involved in the case. However, the newspaper does not share any other details. There are two exceptions here: First, the newspaper gives many more details about cases in which civilians are killed and then proceeds to criticize the killing of civilians. For example, in the case in which 35 civilians (smugglers) were killed as a result of bombing from planes by the army, the newspaper disclosed many more details than it had shared about other cases.

\section{The government bombed the public: 35 dead.}

The air force bombed the villagers who were entering Turkey from the border with their mules loaded with cigarettes. 35 of them were killed, and 3 of them injured. ... A group of people from the village of Ortasu in Uludere in Sirnak. were bombed by the Turkish air force last night while they were crossing the border with their mules loaded with smuggled cigarettes. 35 people were killed during the attack. Most of them were under the age of 18. One had received a call from bis mother while on his way back to Turkey. His mother told him not be scared if he saw any soldiers. She stated, "If the soldier askes you to stop, stop. Do not try to escape from them. They won't burt you."

In the same way, the newspaper Taraf provided detailed information in the news about the counterterror operation in which a civilian died as a result of the shellfire — and criticized this operation.

The second outstanding issue is that the newspaper expresses that there were a lot of casualties in an analytical way, providing many more details. In the news about the terrorist activity on June 15th, 2011 in Silvan, during which 13 soldiers and 7 terrorists were dead, the newspaper used critical language to report the incident and provided detailed information.

Blood in Silvan: 13 soldiers and 7 terrorists are dead. 7 soldiers are injured. Warlike forces are again in action.

Abdullah Ocalan says, 'We agree with the government with regard to the peace council,' but it was one of the bloodiest conflicts of the year. According to initial reports, the PKK ambushed the military forces. Two generals went to the region to inspect the damage and operations are still in progress. 13 soldiers are dead 7 soldiers are injured. 7 members of PKK are also dead as a result of the operation. Sources from the region specify that that PKK ambushed troops, whixh means that this is the first PKK attack in years. Ambush and 
Töngür, A., \& Kara, H. B. (2016). Critical discourse analysis on the news about terrorism: An analytical study on Turkish media. International Journal of Human Sciences, 13(1), 1629-1643. doi:10.14687/ijhs.v13i1.3663

battle news from Silvan fell like a bomb on the capital. The Prime Minister cancelled his trip

to Istanbul and met with the chief of staff, the undersecretary of the Turkish National

Intelligence Service, and his advisory board.

When the Taraf reporting style was analyzed, it was found that the newspaper does not provide the source of the news. However, the Taraf does use information that comes from different official sources.

According to military representatives, terrorists tried to break into a military base.

$H P G$, the military side of the PKK, explained by the way of their news agency, Firat,

that only 3 members of the PKK are dead.; The governor of Mardin announced that two citizens, presumed terrorists, were shot accidentally.; The interior ministry announced that, as a result of the counterterror operations in Celtikli Village in Bitlis, 14 women terrorists were killed. This was the first case in 30 years within this war.

Besides, if the newspaper is not sure about the information received in relation to a particular case, or if there is a probability that the society will react to the news or the case, it specifically stresses that there is no official explanation from official representatives.

... a soldier and a member of the PKK died. There is still no explanation from the governor; In Semdinli Hakkari, The battle between the PKK and the military is nine days long; however, no explanation is forthcoming from the government and military representatives.

The newspaper Taraf does not provide information about the background of the case, its social and economic effects, or solutions for terrorism. However, the newspaper uses terminology which reflects its ideology that the war should end and the problem should be solved by the way of dialogue consensus.

While some were talking about the dialogue and peace council one month ago, the

PKK's serial attacks ended the dialogue.

Warlike forces are again in action. Abdullah Ocalan says, 'We agree with the government with respect to the peace council', but this was one of the bloodiest conflict of the year.

As seen above, by using terms such as 'blood', 'war', and 'battle', the newspapers attempts to convey that war is a bad thing for society. Besides, in the articles, terms are used such as 'peace', 'solution process', and 'dialogue'-and this is done intentionally to support the environment of peace and dialogue.

It is clear here that the newspaper supports the solution process, and believes that peace, human rights, and the right to life will be upholded as a result of this process. Therefore, the newspaper reacts harshly to terrorist activities which harm this process.

\section{Discussion and Results}

This study shows that news on terror and terrorism in Turkey promotes discrimination via the us vs. them or others mentality, which was developed by Van Dijk in his theory. Thus, the state is on one side and the Kurds are on the other side (Durna and Kubilay, 2010b). In the news, the ruling ideology presents state and law enforcement as us and terrorists and the Kurdish people as them.

As it is claimed in previous studies (Karaduman and Batu, 2011), the sample newspapers of this study use active or passive voice in their news texts to reflect their particular ideology. For example, the newspaper Hurriyet uses active voice in its language for referring to terrorists and passive voice for law enforcement officers. The newspaper Yeni Safak uses passive voice in its language for referring to terrorists, but does not use verbs in sentences referring to law enforcement officers. The newspaper Taraf uses active voice in its language to refer to both law enforcement officers and terrorists.

As claimed by Batu and Karaduman (2011), slain law enforcement officers are identified and sanctified as Martyrs as a result of the ruling ideology. Consistent with Batu and Karaduman's study, it is seen in this study that newspapers Hurriyet and Yeni Safak also 
Töngür, A., \& Kara, H. B. (2016). Critical discourse analysis on the news about terrorism: An analytical study on Turkish media. International Journal of Human Sciences, 13(1), 1629-1643. doi:10.14687/ijhs.v13i1.3663

use this term in reference to law enforcement officers, in order to exalt and sanctify them. However, the Taraf does not discriminate between law enforcement officers and terrorists, and employs the term dead in both cases.

As claimed by Karaduman and Batu (2011), macro analysis of the news put forth that the reports are prepared based on statements from official sources. In this study, it is seen that newspapers Hurriyet and Yeni Safak utilize official sources to gather the news but, the Taraf sometimes uses also different sources besides official sources.

Van Dijk claims that the news reflects the accepted norms of society (Bilgin, 2014). In accordance with this theory, newspapers Hurriyet and Yeni Safak aim with their reporting to engage the emotions of people and uphold the popular values in news texts, through the use of honorific and sanctifying terms for slain law enforcement officers and their families. By doing so, these newspapers exemplify law enforcement officers and their families in the eyes of society and thus identify them as $u s$. On the other hand, also the Taraf employs emotional verbiage but, in doing so, aims to support human rights and peace.

Another important result of this study is that while newspapers Hurriyet and Yeni Safak reflect the ruling ideology, the Taraf supports values like human rights, the right to life, and peace. The Hurriyet and Yeni Safak associate terrorist attacks with the eastern and southeastern part of Turkey, where most of the Kurdish population is living.

Another common denominator with newspapers Hurriyet and Yeni Safak is their gender discrimination in their news reporting. These newspapers particularly stress the gender of slain terrorists if they are women. Furthermore, it was found that there is no change in their policies before and after the solution process. However, the newspaper Taraf reacts to terrorist attacks which will cause harm especially after the solution process.

Notwithstanding the foregoing, all these three newspapers use terminology that expresses hatred. Besides, all three newspapers do not provide background information on the case in their news reports. Newspapers provide information only about casualties, the reactions of the victims' relatives, and the duration or time of the operation. No information is offered about the motivations behind the occurrence and the solutions for the devastation brought about by the terror incident.

In light of the analysis of this study, it can be claimed that there are serious problems in terror news reporting by newspapers in Turkey. It can also be said that newspapers encourage further polarization in society, rather than develop solutions to handle terrorism news better. Therefore, in counterterrorism, the government should develop policies to promote social integrity and newspapers should use integrative terminology accordingly.

In this context, the language and terminology which express hatred must not be used. While reporting terrorist activity in the news, the media should not draw attention to the wrong thing by specifying the location of an incident. Furthermore, the distinction made in describing victims differently-that is, law enforcement officers as martyrs and terrorists or civilians as dead or killed - must end.

While newspapers are contributing to widening the chasm between us and them, they do not criticize the state, public order, and society in order to protect $u s$. If newspapers get information also from different sources in addition to the official sources, and if they ultimately superficial knowledge, they will be able to provide more realistic information from all aspects of an issue. This kind of information will be much more beneficial so that the government will be able to see reality and thus, develop better counterterrorism policies. 
Töngür, A., \& Kara, H. B. (2016). Critical discourse analysis on the news about terrorism: An analytical study on Turkish media. International Journal of Human Sciences, 13(1), 1629-1643. doi:10.14687/ijhs.v13i1.3663

\section{References}

Akalın, Mehmet, (2014), "Historical Processes INTERPOL Went Through in the Fight Against Terrorism”, International Journal of Security and Terrorism, 5(1), 103-117.

Altun, Nurullah, (2014), “The Paradox of Social Capital: Terrorism”, Turkish Journal of Police Studies, 16(1), 63-80.

Akbulut, Fatih ve Beren, Fatih, (2012), "Perceived Effects of an Integrated Approach to CounterTerrorism within the Context of Social Policy Implications: Case of Suruc District", Journal of Academic Inquiries, 7(2), 257-283.

Altun, Nurullah, (2013), "Identity in Modern Turkey: From Kurdish Identity to Kurdish Issue", Journal of Academic Inquiries, 8(2), 45-67.

Amichai, Erez, (2009), “The Role Of The Media In Counter-Terrorism”, Mustafa Ozguler; Ali Ozdogan; A. Sait Yayla; Ekrem Mus and Halim İltas (Ed.), Terrorism A Global Perspective, Washington:The Turkish Institue for Security and Democracy, 239-243.

Balci, F. (2008). Politicization of kurdish question through human rights discourse in Turkey. ProQuest.

Barkey, H. J. (2000). Turkey's Kurdish question. Rowman \& Littlefield Publishers.

Best, Steven and Nocella, Anthony J., (2006), "Terörizmi Tanımlamak", http://www.birikimdergisi.com/guncel/terorizmi-tanimlamak, Retrieved on December 27.

Bilgin, Nuri, (2014), Sosyal Bilimlerde İçerik Analizi, Ankara:Siyasal.

Birand, M. A. (1992). Apo ve PKK [Öcalan and the PKK]. Istanbul, Turkey: Milliyet Yayınları.

Bozarslan, H. (2003). Kurdish nationalism in Turkey: from tacit contract to rebellion (1919-1925). Essays on the Origins of Kurdish Nationalism (Costa Mesa, CA: Mazda, 2003), 165.

Ciment, J. (1996). The Kurds: State and Minority in Turkey, Iraq, and Iran. Facts on file.

Demirli, Aylin, (2011), “Terrorism, Psychological Effects and Intervention Models”, Turkish Psychological Counseling and Guidance Association, 4(35), 66-78.

Durna, Tezcan ve Kubilay, Çağla, (2010a), “Söylem Kuramları ve Eleştirel Söylem Çözümlemeleri”, Tezcan Durna (Ed.), Medyadan Söylemler, İstanbul:Libra.

Durna, Tuncay ve Kubilay, Çağla, (2010b), "Basının Şiddeti: Siyasal Gösterilerde "Polise Taş Atan Çocuklar” Örneği”, Ankara Üniversitesi Siyasal Bilgiler Fakültesi Dergisi, 65(3), 51-85.

Gans, H. J. (1979). Deciding what's news: A study of CBS evening news, NBC nightly news, Newsweek, and Time. Northwestern University Press.

Gitlin, T. (1980). The whole world is watching: Mass media in the making \& unmaking of the new left. Univ of California Press.

Göka, E., Topçuoğlu, A., Aktay, Y., (1999), Önce Söz Vardı Yorumsamacıllk Üzerine Bir Deneme, İkinci Bask1, Ankara:Vadi.

Gunter, M. M. (1997). The Kurds and the future of Turkey. Macmillan.

Imset, I. G. (1992). The PKK: a report on separatist violence in Turkey;(1973-1992). Turkish Daily News.

Kanat, Selim, (2014), “The Past The Present And The Future Of Terrorism: A Political Realist Assessment", Suleyman Demirel University The Journal of Faculty of Economics and Administrative Sciences, 19(3), 195-210. 
Töngür, A., \& Kara, H. B. (2016). Critical discourse analysis on the news about terrorism: An analytical study on Turkish media. International Journal of Human Sciences, 13(1), 1629-1643. doi:10.14687/ijhs.v13i1.3663

Karaduman, S. ve Batu, N. M., (2011). “Televizyon Haberlerinde Terörizm Olgusunun TRT'nin Haber Söylemi Bağlamında İncelenmesi”, Selçuk Üniversitesi Sosyal Bilimler Enstitüsü Dergisi, (25), 359-374.

Köseli, Mutlu, (2006), "Poverty Inequality \& Terrorism Relationship in Turkey”, A Dissertation for the degree of Doctor of Philosophy at Virginia Commonwealth University.

Kutschera, C. (1994). Mad Dreams of Independence: the Kurds of Turkey and the PKK. Middle East Report, 12-15.

McDowall, D. (2003). Modern History of the Kurds. IB Tauris.

Shoemaker, P., \& Reese, S. D. (1996). Mediating the message. Theories of influences on mass media content (2nd ed.). White Plains, N.Y.: Longman.

Sigal, L. V. (1974). Reporters and Officials: The Organization And Politics Of Newsmaking, Lexington Books.

Şahin, İsmail, (2014), "International Cooperation against Terrorism in the Context of International Relations Theories", International Journal of Security and Terrorism, 5(1), 69-84.

Şeker, M., Rengim, S. ve Çavuş, S. (2012), “Wikileaks Haberlerinin Türk Basınındaki Söylemi”, Türkiyat Araştırmaları Dergisi, 31, 379-400.

Tuchman, G. (1978). Making news (Vol. 147). New York: Free Press.

Van Dijk, Teun A., (1982), Towards A Model Of Ethnic Prejudice In Cognition And Discourse, Amsterdam: Universtiy of Amsterdam.

Van Dijk, Teun A., (1988), News as Discourse, New Jersey:Lawrance Earlbaum Assaciates Publication.

Van Dijk, Teun A., (2006), "Ideology and Discourse Analysis", Journal of Political Ideologies. $11(2), 115-140$.

Yavuz, M. H. (2001). Five stages of the construction of Kurdish nationalism in Turkey. Nationalism and Ethnic Politics, 7(3), 1-24.

Yurdigül, Yusuf and Balc1, Fatih, (2012), “Terörle Mücadelede Manipülasyon Arac1 Olarak Televizyon Haberleri’, Oğuzhan Başıbüyük; Alper Sözer and Nurullah Altun (Ed.), Terörle Mücadelede Makro ve Mikro Perspektifler, 281-297. 